\title{
Import Demand Function of Rice in Indonesia
}

\author{
Agung Dwi Prasetyo ${ }^{1 *}$, Ratya Anindita ${ }^{2}$ \\ Social Economic, Faculty of Agriculture, Brawijaya University, Jl. Veteran, Malang 65145, East Java, \\ Indonesia.
}

Diterima: 25 Juli 2016; Direvisi: 26 Juli 2016; Disetujui: 27 Juli 2016

\begin{abstract}
To fulfil the need of rice is to increase the domestic production, which is the one of the government's policy. However, by increasing the population, the demand of rice will also increase and the effort of increase the domestic productivity cannot supply the need of domestic rice. So, to cover the shortage the government makes decision to import rice from other countries. Gross Domestic Product (GDP) also increased after monetary crisis in 1998. In the fact of the import of rice is occurred when the statistical data showed that the supply of rice in Indonesia is surplus. The aim of this research is necessary to study the factors which influence the import of rice in Indonesia. The analysis method used is multiple linear regression analysis model with Error Correction Model (ECM). Based on the research proven that partially or jointly the gross domestic product, the consumption, the price of rice in world market are influence significantly toward the import of rice in Indonesia.
\end{abstract}

Keywords: production; demand; price; rice import; ECM

\section{Introduction}

Indonesia is one of the countries with the largest number of people occupying the fifth position in the world with the population over 240 million people that have an impact on the high national food needs, especially on demand for rice because rice is the staple food of Indonesia's population. This is reinforced by Statistics Indonesia in 2013, showed that an increase of the national rice consumption in 2001 of $32,283,326$ tons per year until 2012 of $39,265,422$ tonnes per year. The level per capita of consumption of rice in Indonesia is very high, because every person in Indonesia consumes rice every year at $139.5 \mathrm{~kg} /$ person. Level of rice consumption per capita per year of Indonesian society has increased annually, while the resulting production has not been able to meet the consumption level of Indonesian society, although domestic production tends to increase, but according to Statistics Indonesia (Statistics Indonesia, 2013) from 2001 to 2012 the difference between production and consumption of rice in Indonesia tend to have a deficit, the worst occurred in 2006 which is deficit of $1,367,055$ tons.

The effort of government to increase productivity in the country are still not able to meet the needs of domestic rice. Views from

\footnotetext{
*Penulis Korespondensi.

E-mail : agungdpras@gmail.com
}

Indonesian rice production from year 2001 to 2012 experiencing increase in the amount of production of approximately 10 million tons of rice are still not able to meet demand for rice (BPS, 2013). The incapacity Indonesia requires Indonesia to conduct international trade which is imports of rice to meet domestic food needs. An inability of a country to provide for the needs of rice can be used as a reflection of the country's economy if domestic rice production remained hosted in their own country or undermined by the presence of imported rice.

Based on the data (Statistics Indonesia) of rice to Indonesia's largest import comes from countries Vietnam as much as 416 thousand tons with a value of US $\$ 233$ million. Rice from Thailand to Indonesia as much as 222 thousand tons with a value of US \$128 million. Followed by rice from India as much as 150 thousand tons with a value of US $\$ 70$ million. Rice from Pakistan total, 36 thousand tons with a value of US $\$ 14$ million and rice from China as many as 1,880 with a value of US $\$ 7$ million (Kompas, 2012). Total rice imports by Indonesia during 2012 was 2.7 million tonnes of rice worth US $\$ 438$ million.

\section{Methodology}

The method used in this research is quantitative analysis using secondary data. The data is processed and analysed using multiple linear regression using time series data. While, the study design conducted to determine demand 
for imported rice in Indonesia through the factors affecting demand for imported rice in Indonesia by using Error Correction Model (ECM), where the model is used to correct the regression equation between the variables that individually are not stationary to return to the equilibrium value in the long term, with the main requirement in the form of the existence of a cointegration relationship between the variables compilers. And analyse the value of elasticity, to identify factors that have the most influence on the determinants of rice import demand in Indonesia.

The necessary data is secondary data in the form of annual time series data from the years 1999 to 2012. Data were collected from various sources and agencies, such as: the Statistics Indonesia, the Food and Agriculture Organization of the United Nations (FAOSTAT), and other institutions that support and websites related to the research. Data obtained include: import rice, the demand (consumption) of rice, world rice prices, the production of rice, the planting area of rice, the productivity of rice, the amount of population growth in Indonesia, and the real gross domestic product of Indonesia.

In the preparation of Indonesia's rice import demand functions, variables used is the gross domestic product, national rice consumption, and world rice prices. These functions can be arranged in the following equation:

$$
\begin{aligned}
& \Delta \mathrm{IBN}_{\mathrm{t}}=\alpha_{0}+\alpha_{1} \Delta \mathrm{PDB}_{\mathrm{t}}+\alpha_{2} \Delta \mathrm{KBN}_{\mathrm{t}}+\alpha_{3} \Delta \\
& \mathrm{HBD}_{\mathrm{t}}+\alpha_{4} \mathrm{ECT}_{\mathrm{t}}+\mu_{\mathrm{t}}
\end{aligned}
$$

\begin{tabular}{|c|c|}
\hline \multirow{2}{*}{\multicolumn{2}{|c|}{$\begin{array}{l}\mathrm{PDB}_{\mathrm{t}} \quad=\text { Real gross domestic product in } \\
\text { period } \mathrm{t} / \text { independent variable (billion ruphias) } \\
\mathrm{KBN}_{\mathrm{t}} \quad=\text { National Rice consumption in } \mathrm{t} \\
\text { period / independent variable (Ton) }\end{array}$}} \\
\hline & \\
\hline $\begin{array}{l}\mathrm{HBD}_{\mathrm{t}} \\
\text { independen }\end{array}$ & $\begin{array}{l}=\text { World rice prices in t period / } \\
\text { riable (US \$) }\end{array}$ \\
\hline $\begin{array}{l}\mathrm{IBN}_{\mathrm{t}} \\
\text { period } \mathrm{t} / \mathrm{a}\end{array}$ & $\begin{array}{l}=\text { National Rice imports in } \\
\text { endent variable (Ton) }\end{array}$ \\
\hline$\alpha_{0}$ & $=$ Constants \\
\hline$\alpha_{1}, \alpha_{2}, \alpha_{3}, \alpha_{4}$ & $=$ Coefficient \\
\hline & $=$ Error Correction Term \\
\hline & $=$ Error Term \\
\hline
\end{tabular}

Description :

\section{Results and Discussion}

\subsection{Stationarity test}

Stationary test is the most important stage in the analysis of time series data to remove autocorrelation that cause data to become stationary, means that the data has the properties of autocorrelation or heteroscedasticity. It will result in lack of good models estimated and will produce a model known as regression spurious. Stationary test in this research using a unit root test.

Based on the test results, stationary test with the Augmented Dickey Fuller (ADF) obtained variables of rice imports, the gross domestic product, national consumption of rice and world rice prices are not stationary at the unit root test, so it is necessary to test the degree of integration that is intended to determine the degree of how much data will be stationary, variables of national rice imports, gross domestic product, consumption of rice and rice prices on the world are stationary at second condition difference with probability value of $<0.005$.

\subsection{Cointegration test}

Cointegration test is one of the methods to indicate the possibility of long-term equilibrium relationship between the dependent and independent variables. From the results that obtain cointegration of variables of gross domestic product, national rice consumption, world rice prices to the national rice imports of residual stationary, or in other words it can be concluded that the analysis model is cointegrated. Thus, based on these tests can be said that there is a long-term relationship among the gross domestic product, national rice consumption, world rice prices to the national rice imports. This is indicated by the value of Agumented Dickey-Fuller (ADF) statistics on the value of the critical values of $5 \%=-3.521685<-0.085673$ with $\mathrm{p}=0.0065<0.05$.

Requirement is needed to show that among the variables studied by looking at the behaviour of residual cointegrated regression equations used. With unit root test revealed that ECT (residual) stationary at the current level. Thus the results of the stationary test data against residual reinforce that among the variables used are cointegrated. In econometric variables that are cointegrated said in the long-term conditions (Long-term Equilibrium).

\subsection{Test Error Correction Model (ECM)}

a. Regression Model Error Correction Model (ECM) (Short Term)

ECM test result is used to find the model of equilibrium in the short term to the long-term equilibrium among the gross domestic products, national rice consumption, world rice prices to 
the national rice import models generated in this research is:

$$
\begin{gathered}
\Delta \mathrm{IBN}_{\mathrm{t}}=(-4.238)+5460.881 \Delta \mathrm{PDB}_{\mathrm{t}}+227.2420 \\
\Delta \mathrm{KBN}_{\mathrm{t}}+(-215.4136) \\
\Delta \mathrm{HBD}_{\mathrm{t}}+(-0.830397) \mathrm{ECT}_{\mathrm{t}}+\mu_{\mathrm{t}} \ldots \ldots \ldots \ldots \ldots \ldots \ldots . . . . .2
\end{gathered}
$$

Based on the results of the dynamic model estimation of Error Correction Model (ECM), it can be said that every $1 \%$ increase in gross domestic product will increase imports by $5.46 \%$, each $1 \%$ increase in national rice consumption will increase rice imports amounted to $2.27 \%$, every $1 \%$ increase in world rice prices will decrease national rice imports amounted to $2.15 \%$. ECT with a probability value of 0.039 or $<0.05$. Thus it can be said that the model of ECM can be used in estimating the factors that affect the national rice imports by the independent variables during the research period or in other words the specification of the model used is valid with a $95 \%$ confidence level.

\section{b. Regression Model Long Term}

From the analysis of the long-term estimation of Error Correction Model as follows: $\Delta \mathrm{IBN}_{\mathrm{t}}=(-6.33079)+513.5925 \Delta \mathrm{PDB}_{\mathrm{t}}+$ $169.3625 \Delta \mathrm{KBN}_{\mathrm{t}}+(-613.8526) \Delta \mathrm{HBD}_{\mathrm{t}}+\mu_{\mathrm{t}} \ldots$ (3)

Based on the results of the long-term model estimation of Error Correction Model (ECM), it can be said that every $1 \%$ increase in gross domestic product in the long term it will increase imports by $5.1 \%$, each $1 \%$ increase in national rice consumption in the long term will increase rice imports by $1.6 \%$, and each $1 \%$ increase in world rice prices in the long run will reduce national rice import by $6.1 \%$.

The residual value of the coefficient is negative which is -6.33 this reflects that the relations between the dependent variable and independent variables away from equilibrium. The relationship between the dependent variable with the independent variable in the long term is of $21 \%$. Thus, it can be said that this happened in the relationship among the level of the variables of gross domestic product, consumption and world rice prices with variable national rice imports by $21 \%$ in the long term, while $79 \%$ in the long term is influenced by other variables outside the model. As said by Gujarati (2012), that the two variables are cointegrated if they have a relationship or long-term equilibrium among these variables.

It means that the gross domestic product, national rice consumption, world rice prices have cointegration relationship with national or imported rice are long-term relationship between the variables. So that in the long term gross domestic product, national rice consumption, world rice prices affect the national rice import demand.

\subsection{Classic assumption test}

Classical assumption test is performed to determine whether the model estimates has met the criteria econometrics, meaning that no serious deviations from the assumptions that must be met to determine the factors that influence the demand for imported rice in Indonesia, both in the short and long term, while the results classic assumption test as follows:

\section{a. Normality Test}

Normality test is testing whether the independent variables in the regression model (gross domestic product, national rice consumption and the price of national rice) and the dependent variable (the national rice imports) normally distributed or not. Otherwise good model if the data distribution is normal or near normal.

According to Firdaus (2011) for detecting normality test can be done kolmogorov-Smirnof, with $\mathrm{H} 0$; data distribution is normal, $\mathrm{H} 1$; data distribution is not normal. Criteria testing that if significance $<0.05$ then $\mathrm{H} 0$ is rejected, which means the data is not normally distributed, and if the significance> 0.05 then $\mathrm{H} 0$ accepted, which means the data are normally distributed.

Smirnov test results Kolmogorov- shortterm model estimation obtained significance value of 0.812 or greater than 0.05 , then the provisions $\mathrm{H} 0$ is accepted which means that the normality assumption is fulfilled.

While, the Kolmogorov-Smirnov test results obtained estimates of long-term significance value of 0.845 or greater than 0.05 , then the provisions $\mathrm{H} 0$ is accepted which means that the normality assumption is fulfilled.

\section{b. Autocorrelation Test}

Autocorrelation test aims to test whether the linear regression model was no correlation between errors in the $t$ period with no errors in $t-$ 1 period (previously). A good regression model is a regression model that is free from the problem of autocorrelation. Test Durbin-Watson of autocorrelation test is between $\mathrm{Du}$ and (4-dU), then there is no autocorrelation in the model.

The test results in the short-term model estimation shows that the national rice import 
variables obtained by Durbin-Watson table at significant level of 0.05 for the value of $n=14$ (number of data) and $\mathrm{k}=3$ (number of independent variables). Unknown value amounted to 2.117 Durbin Waston dU value obtained was 1.778 and the value of $4-\mathrm{dU}$ was 2.222 . So that $1.778<2.117<2.222$. As well as the long-term estimation model known value of 2.220 Durbin Waston dU value obtained was 1.778 and the value of $4-\mathrm{dU}$ was 2.222 . so that $1.778<2.220<2.222$. It can be concluded that there is no autocorrelation in the model of shortterm and long-term.

\section{c. Multicolinearity Test}

Test Multicolinearity is a state where the independent variables in the regression equation correlated (correlation) are close to each other. Variables of gross domestic product, national rice consumption and world rice prices should be free of symptoms multicolinearity. A good regression model is a model that is free of these problems. Multicolinearity problem can be determined by looking at the value of Variance Inflation Factor (VIF) in each variable. Basis for a decision is VIF $>10$ and the value of tolerance $<0.1$, the variables has multicolinearity issues with other variables.

Variables of gross domestic product, national rice consumption variables and national rice price in the short term and long term have no correlation or relationship between the variables with other variables, which means free from multicolinearity because it has VIF $<10$ and tolerance values $>0.1$.

\section{d. Heteroskidastity Test}

Heteroscedasticity test is used to test whether a regression model residual variance of the inequality occurs in one observation to others remain, it is called heteroscedasticity. Heteroscedasticity test can be determined by looking at the picture scatterplot obtained from testing the model. Decision-making occurs if there are certain patterns in the picture, such as dots that form a particular pattern occurs on a regular basis it is concluded heteroscedasticity.

\subsection{Statistic test}

a. The coefficient of determination $\left(\mathrm{R}^{2}\right)$

Determinants of analysis used to determine the percentage of the effect of the gross domestic product, national rice consumption and world rice prices to the national rice imports. Results of the coefficient of determination on the estimated short-term models indicate that the value of 0.488 or 48.8 percent of the variation of the dependent variable is able to be explained by variations in the set of explanatory variables. While the remaining 51.2 percent variation of the dependent variable explained by other variables outside the model. As for the estimation of the long-term model of Durbin Waston known value of 2,220 $\mathrm{dU}$ value obtained was 1.778 and the value of 4$\mathrm{dU}$ was 2,222 . So that $1.778<2.220<2.222$.

\section{b. F Test (Test Simultaneously)}

$F$ test is used to verify whether the independent variables (GDP, consumption of rice, the price of rice) together have a significant effect both positive or negative, on the dependent variable (the national rice imports). Based on the results of the $\mathrm{F}$ test calculations on the estimated short-term model of the national rice imports obtained results $\mathrm{F}$ calculate equal to 3.174 . The calculated $\mathrm{F}$ value higher than the $\mathrm{F}$ table value of 2.25 at the 90 percent confidence level or $\alpha=$ $10 \%$. As for the long-term model estimation results obtained $\mathrm{F}$ value equal to 3.04. The calculated $\mathrm{F}$ value is greater than the $\mathrm{F}$ table value of 2.25 at the 90 percent confidence level or $\alpha=10$ percent. This shows that the simultaneous variables gross domestic product, national rice consumption and world rice prices in the short term and long term simultaneously significantly influence the national rice import demand.

\section{c. $\quad$ T test (Test Partial)}

Individual parameter significance test $(\mathrm{t}$ test) was conducted to see the significance of the influence of the independent variable on the dependent variable individually and consider other variables constant. Partially in the short term and long term variables of gross domestic product and the global rice price significantly influence the national rice imports, because it has a probability value of $\alpha<5 \%$. While variable national rice consumption does not significantly influence the national rice imports because it has a probability value greater than $5 \%$.

\subsection{Import elasticity}

The concept of elasticity is used to determine the change of exogenous variables (for example: gross domestic product, consumption of rice and world rice prices) which will influence on other variables (eg: imported rice) as an endogenous variable. 
Import elasticity of each variable can be calculated with the following formula:

Elasticity $=\frac{d y}{d x} X \frac{\bar{y}}{\bar{x}}=$ Coefficient $X \frac{\bar{y}}{\bar{x}}$

Import elasticity of calculation formula mentioned above, the results as follows:

Import elasticity of GDP $\quad=1.5$

Import elasticity of National Rice Consumption variable $\quad=0.3$

Import elasticity of World Rice Prices variable

$$
=-1.4
$$

Explanation on the calculation of import elasticity can be described as follows:

a. Gross domestic product is significantly positive effect on rice imports with a value of elasticity of 1.5. It means changing one percent change in gross domestic product of Indonesia would lead to an increase in the volume of rice imports by 1.5 percent. This is due to the import of rice carried out when Indonesia's gross domestic product increased. Increasing gross domestic product showed the public revenues also increased, so that purchasing power will also increase, but if the supply or production of rice in the country is smaller than the demand, the government will import the rice. Research conducted by Yulianti (2013) also includes a factor of gross domestic product as the factors that influence the demand for rice imports.

b. The value of the national rice consumption elasticity is 0.3 or $0>\mathrm{E}<1$ indicates that the variable national rice consumption is not very influential (non-responsive) to variable import of rice. Change of one percent of independent variable would result in a change on dependent variable less than 1 percent or 0.3 percent. This is caused by the consumption of rice in Indonesia that largely influenced by per capita consumption. It deals with the rate of growth of Indonesia's population that is not too fast with an average growth rate of only 0.1 percent a year. This is supported by research conducted by Kurniawan (2013), that the population does not significantly influence the national rice imports in both the short and long term.

c. While the world rice price factor significantly negative effect on the value of the elasticity of -1.4 or value of $E>1$ indicates that the variable world rice prices significantly affect the national rice import variables. This shows that every 1 percent increase in the world price of rice would be comparable to a decrease of 1.4 per cent drop in national rice imports. This is because the price of imported rice on world rice prices fell, importers will import rice while import prices cheaper than the price of domestic rice. The price difference between imports with domestic prices are closely linked to the advantage of internal factors such as the low inflation in the importing country and external factors such as the increase in state revenue importer. Research conducted by Syamsurizal, (1990) also includes the world rice price factor as the factors that influence the demand for rice imports. Judging from the value of the elasticity of the independent variable (gross domestic product, national rice consumption, and world rice prices) the most influence on the dependent variable (the national rice imports) is variable gross domestic product by the elasticity of 1.5. As for the variables national rice consumption and world rice price elasticity values are respectively 0.3 and 1.4 .

\section{Conclusion}

Variable of gross domestic product in the short term and long term have positive and significant impact on the import of rice nationwide, then variable of national rice consumption in the short term and long term impact positively and significantly to rice imports nationwide, while the variable world rice prices in the long term and term short significant have negative effect on the national rice imports. By using a confidence level of $95 \%$.

Judging from the value of the elasticity of the independent variables (gross domestic product, national rice consumption, and world rice prices) the most influence on the dependent variable (the national rice imports) is variable gross domestic product by the elasticity of 1.5 . As for the variables of national rice consumption and world rice price elasticity values are respectively 0.3 and 1.4 .

\section{References}

Badan Pusat Statistik. 20013. Statistik Indonesia 2013. Jakarta. 
Bank Indonesia, 1994. Statistik Ekonomi dan Keuangan Indonesia, Jakarta : Bank Indonesia.

Boediono, 1983. Ekonomi Internasional, Yogyakarta : BPFE-UGM.

Dachlianai, Diesy. 2006. Permintaan Impor Gula di Indonesia. Tesis UNDIP. Semarang Jawa Tengah.

Djunaedi, A. 2012. Analisis Faktor-Faktor yang Mempengaruhi Konsumsi Beras di Indonesia periode 2001-2010. Skripsi. Malang. Universitas Ma Chung.

Eko Atmadji, (2004). Jurnal Ekonomi Pembangunan. Analisis Impor Indonesia, (Online), Vol.9. No.1: 33-46, (http://journal.uii.ac.id/index.php/

JEP/article/view, diakses 08 Februari 2015).

Gujarati, Damodar. 2012. Dasar-dasar Ekonometrika: Buku 2 Edisi Kelima. Jakarta: Erlangga.

Lindert, H. Peter and Charles P. Kindleberger, 1988. Ekonomi Internasional, Terjemahan Ir. Burhanudin MA, Edisi Kedelapan, Jakarta : Penerbit Erlangga.

OECD (2012), OECD Review of Agricultural Policies: Indonesia 2012, OECD Publishing. doi: 10.1787/9789264179011en.

Pracoyo, Tri Kunawangsih. dan Antyo Pracoyo. 2005. Aspek Dasar Ekonomi Makro di Indonesia. Jakarta : PT Grasindo.

Samuelson, Paul A. 1983. Economics, Singapore : Mc. Graw- Hill Publishing Company.

Sudarman, Ari, 1992. Teori Ekonomi Mikro, Edisi Ketiga, Yogyakarta : BPFEUGM.

Yulianti, Desyana. 2013. The Influence of Macroeconomics Indicators To Import Rice In Indonesia. Jurnal Ekonomi. Dosen Tetap Institut Perbanas. 